Article

\title{
Nutritional Value and Antimicrobial Activity of Pittosporum angustifolium (Gumby Gumby), an Australian Indigenous Plant
}

\author{
Anh Dao Thi Phan ${ }^{1,2} \mathbb{D}$, Mridusmita Chaliha ${ }^{1}$, Hung Trieu Hong ${ }^{1}{ }^{(}$, Ujang Tinggi $^{3}$, \\ Michael E. Netzel ${ }^{1, *(\mathbb{D})}$ and Yasmina Sultanbawa ${ }^{1, *(\mathbb{D})}$ \\ 1 ARC Industrial Transformation Training Centre for Uniquely Australian Foods, Centre for Nutrition and \\ Food Sciences, Queensland Alliance for Agriculture and Food Innovation, The University of Queensland, \\ Coopers Plans 4108, Australia; a.phan1@uq.edu.au (A.D.T.P.); m.chaliha@uq.edu.au (M.C.); \\ h.trieu@uq.edu.au (H.T.H.) \\ 2 Department of Food Technology, Faculty of Agriculture, Can Tho University, Can Tho 94000, Vietnam \\ 3 Health Support Queensland, Queensland Health Department, Coopers Plans 4108, Australia; \\ Ujang.Tinggi@health.qld.gov.au \\ * Correspondence: m.netzel@uq.edu.au (M.E.N.); y.sultanbawa@uq.edu.au (Y.S.)
}

Received: 29 May 2020; Accepted: 1 July 2020; Published: 6 July 2020

\begin{abstract}
The indigenous endemic plant $P$. angustifolium has received attention for nutraceutical and therapeutic applications in Australia. This study investigates for the first time the nutritional value (macro- and micronutrients, minerals, trace elements, polyphenols, carotenoids, saponins and antioxidant capacity) and antimicrobial activity of different botanical parts of P. angustifolium, either collected from the wild or cultivated. Different botanical tissues, geographic location and growing condition (wild vs. cultivated) showed significant $(p<0.05)$ effects on the tested bioactive compounds, with the leaves having significantly $(p<0.05)$ higher levels than the stems. Saponins and polyphenols could be identified as the main bioactive compounds in the leaves with up to $4 \%$ per dry weight. The extracts of P. angustifolium leaves and stems showed strong antioxidant and antimicrobial activities, especially against Candida albicans. These activities correlated $\left(R^{2}=0.64-0.92\right.$; $p<0.05)$ with the levels of polyphenols and saponins, indicating their biologic potential. Findings from this study may provide information for future applications of $P$. angustifolium in the functional ingredient or nutraceutical industry.
\end{abstract}

Keywords: Gumby Gumby; Australian indigenous plant; nutrients; bioactive compounds; antimicrobial activity

\section{Introduction}

There is a global demand for natural ingredients from plant sources with multifunctional properties for application in the food and nutraceutical industries. In 2018, the market for herbal dietary supplements in the United States increased by $9.4 \%$ and the value of this market reached an estimated 8.842 billion dollars across all market channels, marking the strongest US sale growth of herbal supplements since 1998 [1]. Similarly, there is a growing demand for foods and medicines that are known for their customary usage by Indigenous communities. These interests range from general desires for prevention from acute and chronic diseases, maintenance of good health, well-being, immune system strengthening and energy sustenance, to seeking out traditional foods/native plants that provide natural antioxidants and antimicrobials. There are many plant bioactive compounds of particular interest such as saponins, polyphenols including tannins and alkaloids, which are known to assist in providing the above benefits to human health and well-being. 
P. angustifolium (common name: Gumby Gumby) is a shrub tree, native to Australia. This species belongs to the genus Pittosporum and the family Pittosporaceae, consisting of approximately 200 species in nine genera [2]. P. angustifolium has been found mainly in inland Australia, New Zealand and many other parts of the world [2]. Different botanical tissues of P. angustifolium have been traditionally used as Indigenous bush medicine across inland Australia for hundreds of years to enhance general health and well-being. The infusions from leaves were used to treat cold and coughs and to induce lactation [3]. Decoction made from the fruits was taken orally or applied to treat skin problems such as eczema and pruritus [2,4]. In addition, P. angustifolium has been traditionally used for treatment of rheumatoid arthritis and other inflammatory conditions [5]. Recently, Madikizela and McGaw [6] summarized information on traditional medicinal applications of the genus Pittosporum for treatment of a wide range of infections such as inflammatory, spasmodic, malarial and microbial infections (e.g., narcotics, chronic bronchitis, leprous infection, rheumatic, bruises, sciatica, chest infection and certain skin diseases). Interestingly, all parts of the Pittosporum plants, including leaf, bark, root, flower, fruit pulp, seed and even wood, have been reported to show potential medicinal applications in many countries such as Australia, China, India and South Africa [6].

The increasing interest in drug discovery from native medicinal plants has led to many studies on extraction, identification and quantification of bioactive compounds in different species of Pittosporum genus, P. angustifolium included [6-14]. Several bioactive compounds have been identified in the crude extracts of P. angustifolium such as triterpenoid saponins in leaves and seeds [7-11], phenolic acids and flavonoids in leaves (Figure 1) [12], tannins and essential oils in leaves and fruits [11]. Among them, triterpenoid saponins, essential oils and non-tannin polyphenols are reported as main bioactive compounds in the Pittosporum genus [6,13], whereas tannins and alkaloids are minor compounds. There seems to be no alkaloids present in the leaves and fruits of P. angustifolium [11,14].

Despite the wealth of available literature on bioactive compounds and their associated medicinal properties, there is still a gap in knowledge regarding potential effects of P. angustifolium bioactive compounds due to different growing conditions (wild vs. cultivated), diverse botanical tissues (leaf vs. stem) and geographical locations. Therefore, the present study aimed (i) to determine proximate composition, minerals and trace elements, bioactive compounds, antioxidant capacity and antimicrobial activity of Australian grown P. angustifolium as an initial measure of their nutritional value and bioactive potential and (ii) to assess the impact of different plant parts, growing conditions and geographic locations on bioactive compounds and associated bioactivities.
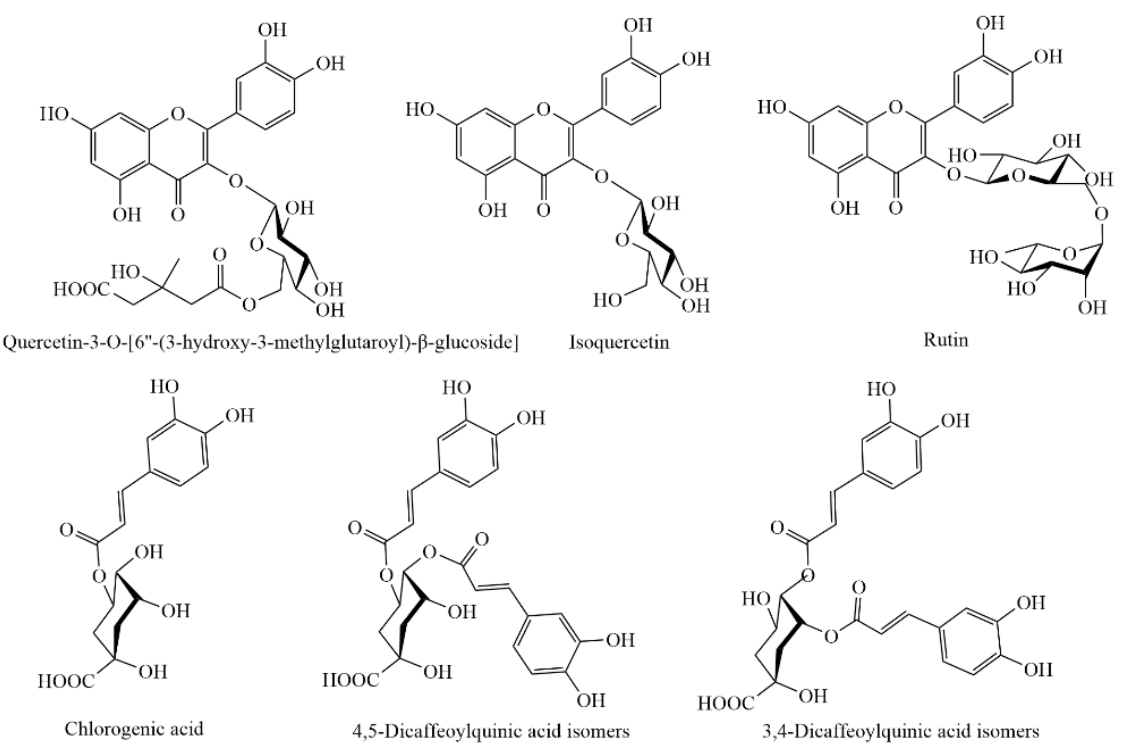

Figure 1. Main polyphenolic compounds identified in P. angustifolium leaves and stem. 


\section{Materials and Methods}

\subsection{Plant Material}

Approximately $5 \mathrm{~kg}$ of P. angustifolium (1 year-old) whole branch (length $\leq 30 \mathrm{~cm}$; stem diameter $<5 \mathrm{~mm}$ ) collected in 2018 from the field (Clermont, Queensland (QLD), Australia) were provided by Gumby Gumby Australia, Ltd. (Clermont, Australia). The cultivated sample was divided into 3 different parts: leaves, stems and the whole branch (without separation as used for traditional medicinal applications). The ratio between leaf and stem was 65-70:30-35 (w/w). The samples were freeze-dried at $-50{ }^{\circ} \mathrm{C}$ for $48 \mathrm{~h}$ (CSK Climateck, CSK Scientific, Brisbane, Australia) and blended into a fine powder using a Waring Laboratory Blender (Australian Scientific, Australia).

The wild harvested sample, collected in 2018 from subtropical forest, included P. angustifolium whole branch from QLD (provided by Gumby Gumby Australia, Ltd.) and leaves from South Australia (SA) (supplied by Bush Food Australia, Ltd., Wilmington, Australia). After harvesting, the samples were air-dried indoors and blended into a fine powder $(\mathrm{ca} .3 \mathrm{~kg})$ as with the cultivated samples. The final (powdered) samples had a moisture content $\leq 5 \%$ and were stored at $-35^{\circ} \mathrm{C}$ for further analysis.

The following abbreviations were used to label the samples: QLD-Cul-WB, QLD-Cul-Leaf, QLD-Cul-Stem (cultivated P. angustifolium whole branch, leaf and stem samples collected in QLD); QLD-Wild-WB (P. angustifolium whole branch collected from the wild in QLD) and SA-Wild-Leaf (P. angustifolium leaves collected from the wild in SA).

\subsection{Reagents}

Polyphenol and carotenoid standards (HPLC grade), including (+/-)-catechin, gallic acid, rutin, isoquercetin, chlorogenic acid, caffeic acid, p-coumaric acid, ferulic acid, lutein, zeaxanthin and trans-beta-carotene, were purchased from Sigma-Aldrich (Castle Hill, NSW, Australia). Ascorbic acid, 2,2-diphenyl-1-picrylhydrazyl (DPPH), oleanolic acid and 1,4-dithiothreitol (DTT) were also from Sigma-Aldrich.

Pteroylmonoglutamic acid (PteGlu), tetrahydrofolate $\left(\mathrm{H}_{4}\right.$ folate), 5-methyltetrahydrofolate (5- $\mathrm{CH}_{3}$ $\mathrm{H}_{4}$ folate), 5-formyltetrahydrofolate (5-CHO- $\mathrm{H}_{4}$ folate), and their corresponding labeled isotopes were sourced from Merck Eprova (Schaffhausen, Switzerland).

Cultures of Staphylococcus aureus (strain 6571) and Escherichia coli (strain 9001) were obtained from the National Collection of Type Cultures (NCTC, Health Protection Agency Center for Infection, London, UK). Candida albicans (strain 90028) was sourced from the American Type Culture Collection (ATCC, In Vitro Technologies Pty, Ltd., Noble Park, Australia). Plate count agar and potato dextrose agar media (Thermo Fisher Scientific, Scoresby, Australia) were used to test antibacterial and antifungicidal activity.

\subsection{Methods}

\subsubsection{Proximate Analysis}

Proximate analysis was performed at Symbio Alliance Laboratories (Eight Mile Plains, Australia), a National Association of Testing Authorities (NATA) accredited laboratory that complies with ISO/IEC 17,025:2005. The following NATA accredited in-house or standard AOAC methods were used: protein (AOAC method 990.03, [15]); total fat (AOAC method 991.36, [16]); saturated, mono-unsaturated, poly-unsaturated and trans fatty acids by gas chromatography with flame-ionization detector (in-house method CFH068.2); dry matter (AOAC method 934.01, [17]); ash content (AOAC method 942.05, [17]); total sugar, total dietary fiber and available carbohydrate by high performance liquid chromatography equipped with refractive index detector (in-house methods CFH001.1, CF057 and CF029.1). Proximate analysis was performed in duplicate including measurement of uncertainty. 


\subsubsection{Mineral and Trace Element Analysis}

Analysis of minerals $(\mathrm{Ca}, \mathrm{K}, \mathrm{Mg}$, $\mathrm{Na}$ and $\mathrm{P}$ ) was performed using inductively coupled plasma optical emission spectrometry (ICP-OES, Agilent 700, Agilent Technologies, Tokyo, Japan) after hot-block digestion. Analysis of trace elements was performed using inductively coupled plasma mass spectrometry (ICP-MS, Agilent 7700) after microwave digestion. The analysis was carried out at the Forensic and Scientific Services, Queensland, a NATA accredited laboratory. Details of the method have been described previously by Akter et al. [18].

\subsubsection{Analysis of Polyphenols}

\section{Extraction of Free Phenolic Compounds}

Extraction of free polyphenols was carried out as reported previously [19], with modifications. Briefly, $200 \mathrm{mg}$ powdered sample was homogenized with $80 \%$ methanol containing $0.1 \% \mathrm{HCl}$ $(v / v)$ using a vortex. The homogenate was subsequently placed in an ultrasonication bath for $30 \mathrm{~min}$ at room temperature (rt) to support the release of phenolic compounds, followed by centrifugation at $3900 \mathrm{rpm}$ for $10 \mathrm{~min}$ at rt (Eppendorf Centrifuge 5804, Hamburg-Eppendorf, Germany). Supernatants were retained, while residues were re-extracted twice followed the procedure described above. The supernatants were combined and subjected to UHPLC-PDA-MS/MS analysis, DPPH radical-scavenging capacity assay and total phenolic content (TPC) measurement. The extraction was carried out in triplicate.

\section{Extraction of Bound Phenolic Compounds}

Extraction of bound phenolic compounds followed Adom and Liu [20] with modifications and details of the method were described previously by Phan et al. [21]. Briefly, following the free phenolic extraction, the residues were subjected to alkaline hydrolysis and subsequently extracted with ethyl acetate. The ethyl acetate extracts were dried at $40{ }^{\circ} \mathrm{C}$ under nitrogen flow and redissolved in $50 \%$ methanol containing $0.1 \%$ formic acid for further analysis.

\section{U(H)PLC-PDA-MS/MS Analysis}

Polyphenols were analyzed using a Waters Acquity ${ }^{\text {TM }}$ UPLC-PDA System (Waters, Rydalmere, Australia) with detailed chromatographic conditions summarized in Supplementary Table S1. Peak identities were confirmed using a Thermo high resolution $Q$ Exactive mass spectrometer equipped with electrospray ionization (ESI) source and a Dionex Ultimate 3000 UHPLC system (Thermo Fisher Scientific Pty, Ltd., Scoresby, Australia). A full MS scan in negative ion mode was acquired from $\mathrm{m} / \mathrm{z}$ 120 to 1000 at a resolving power of 70,000 full-width at half maximum. For the compounds of interest, a MS/MS scan range of $m / z$ 100-1000 was selected, with normalized collision energy (NCE) at $35 \mathrm{~V}$. The compound identification was based on comparing retention time, UV-Vis spectra, mass spectra and fragmentation patterns with those obtained from available standards and/or literature. Polyphenols were quantified at $320 \mathrm{~nm}$, using external calibration curves of different polyphenol standards as stated in Section 2.2.

\subsubsection{Analysis of Carotenoids}

\section{Extraction}

Carotenoid extraction followed the method previously reported by Djuikwo et al. [22] with slight modifications. Approximately, $100 \mathrm{mg}$ powdered sample was homogenized with acetone and $95 \%$ ethanol containing $0.1 \%$ butylated hydroxytoluene (BHT) $(w / v)$. Next, the samples were subjected to saponification for $30 \mathrm{~min}$ at rt using $\mathrm{KOH}(20 \%$ in methanol, $w / v)$, while shaking at $100 \mathrm{rpm}$. Following the saponification, hexane/dichloromethane (DCM) mixture (70:30, v/v) containing $0.1 \%$ BHT was added to extract carotenoid compounds. $\mathrm{NaCl} 10 \%(w / v)$ was added to improve phase separation, followed 
by centrifugation at $3900 \mathrm{rpm}$ for $5 \mathrm{~min}$ at rt. The upper hexane/DCM layer was collected, combined and then evaporated under nitrogen until dryness. The crude extract was freshly reconstituted in methanol/methyl tert-butyl ether (50:50, v/v) containing 0.1\% BHT for UHPLC-PDA-MS/MS analysis. All procedures were performed on ice, under dim light, using amber glassware where possible. The extraction was performed in triplicate.

\section{U(H)PLC-PDA-APCI-MS/MS Analysis}

Carotenoids were analyzed using a Waters Acquity ${ }^{\mathrm{TM}}$ UPLC-PDA system (Supplementary Table S1). Detected carotenoid compounds were identified using the same UHPLC-MS/MS system as described for the polyphenol analysis (Section 2.3.3) but employing an atmospheric pressure chemical ionization (APCI) operated in positive mode. A full MS scan $(m / z 80-1200)$ was acquired. For the compounds of interest, a MS/MS scan range of $m / z$ 80-650 was selected, with NCE at $20 \mathrm{~V}$. Carotenoids were quantified at $450 \mathrm{~nm}$, using external calibration curves of all-trans beta carotene, lutein and zeaxanthin. Concentrations of carotenoid standards were determined spectrophotometrically (Cintra 303, GBC Scientific Equipment, Braeside, Australia) using the specific molar absorption coefficients of carotenoids in solutions [23].

\subsubsection{Vitamins}

\section{Folates}

Folates were analyzed by stable isotope dilution assay (SIDA) and UHPLC-PDA-MS/MS (Striegel et al. [24]). Briefly, $100 \mathrm{mg}$ of powdered sample was extracted with MES buffer ( $\mathrm{pH}$ 5). Labeled isotopic compounds (IS), including $\left[{ }^{13} \mathrm{C}_{5}\right]$-PteGlu, $\left[{ }^{13} \mathrm{C}_{5}\right]-\mathrm{H}_{4}$ folate, $\left[{ }^{13} \mathrm{C}_{5}\right]-5-\mathrm{CH}_{3}-\mathrm{H}_{4}$ folate and $\left[{ }^{13} \mathrm{C}_{5}\right]-5-\mathrm{CHO}-\mathrm{H}_{4}$ folate, were added at appropriated concentrations. A Shimadzu UHPLC-ESI-MS/MS system (Shimadzu Corp., Kyoto, Japan) equipped with a Shimadzu 8060 triple quadrupole mass spectrometer was employed (Supplementary Table S1). Multiple reaction monitoring (MRM) in positive mode was optimized to quantify individual folate vitamers and their corresponding labeled isotopes. External calibration curves for quantification of folate vitamers were constructed based on the ratios of peak areas of analytes vs. IS.

\section{Vitamin C}

Ascorbic acid (L-AA) extraction and analysis followed Campos et al. [25], with slight modifications. Briefly, $200 \mathrm{mg}$ powdered sample was extracted with 3\% meta-phosphoric acid containing $8 \%$ acetic acid and 1-mM EDTA. The reduction of dehydroascorbic acid (DHAA), which was also present in the extracts/samples, to L-AA was performed following the method of Spinola et al. [26]. Vitamin C (L-AA + DHAA) was determined using a Waters UPLC-PDA system (Supplementary Table S1) and an external calibration curve of L-AA at $245 \mathrm{~nm}$ was used for quantification.

\section{Non-Folate B Vitamins}

Analysis of vitamins B1, B2, B3, B5, B6, B7 and B12 was conducted at Symbio Alliance Laboratories, using NATA accredited in-house HPLC-PDA methods (CFH363, CFH364 and CFH366). The analysis were performed in duplicate including measurement of uncertainty.

\subsubsection{Total Phenolic Content}

The free and bound polyphenol extracts were used for total phenolic content (TPC) measurement employing the Folin-Ciocâlteu reagent [27]. A microplate absorbance reader (Sunrise, Tecan, Maennedorf, Switzerland) was used at $700 \mathrm{~nm}$. TPC was expressed as $\mathrm{mg}$ of gallic acid equivalents (GAE) per $\mathrm{g}$ of sample, using an external gallic acid standard curve (0-105 mg/L). 


\subsubsection{DPPH Radical-Scavenging Capacity}

The DPPH free radical-scavenging assay [28] was used to determine the radical-scavenging capacity of the samples. The scavenging capacity was measured on a microplate absorbance reader (Sunrise, Tecan) at $517 \mathrm{~nm}$. Ascorbic acid $(0-0.1 \mathrm{mg} / \mathrm{mL})$ was added for comparison. The \% DPPH scavenging capacity was calculated using the following equation:

$$
\% \mathrm{DPPH}=\left[\left(\mathrm{A}_{0}-\mathrm{A}_{1}\right) / \mathrm{A}_{0}\right] \times 100 ;
$$

where $\mathrm{A}_{0}$ and $\mathrm{A}_{1}$ are the absorbance values of the control and the test samples, respectively.

\subsubsection{Total (Condensed) Tannins}

Extraction of tannins followed the method described by Karamac et al. [29] with slight modifications. Briefly, approximately $1 \mathrm{~g}$ powdered sample was extracted with acetone in a sonication bath $\left(70^{\circ} \mathrm{C}\right.$, $15 \mathrm{~min}$ ). After cooling, the supernatant was retained by centrifugation at $3900 \mathrm{rpm}$ for $10 \mathrm{~min}$. The extraction was repeated 3 times and the supernatants were combined and concentrated at $40{ }^{\circ} \mathrm{C}$ in a miVac sample Duo concentrator (Genevac, Inc, Gardiner, NY, USA). The dried extract was redissolved in methanol and subjected to the Vanillin-HCl assay (Price et al. [30]), using a Sunrise microplate reader at $500 \mathrm{~nm} .(+/-)$-Catechin $(0-1.5 \mathrm{~g} / \mathrm{L})$ was used to prepare an external calibration curve. Total tannin content (TTC) was expressed as $\mathrm{mg}$ of catechin equivalents (CaE) per $100 \mathrm{~g}$ of sample.

\subsubsection{Total Saponins}

Extraction and quantification of saponins followed the spectrophotometric method described previously [31,32] with modifications. Approximately $1 \mathrm{~g}$ powdered sample was extracted with $80 \%$ methanol at rt while shaking on an orbital shaker (RP1812, Paton Scientific, Victor Harbor, Australia) at $100 \mathrm{rpm}$ overnight. The supernatant was collected after centrifugation (3900 rpm, $10 \mathrm{~min}$ ), while the residue was re-extracted twice with $80 \%$ methanol (for $1 \mathrm{~h}$ ). The supernatants were combined and evaporated until dryness at $40{ }^{\circ} \mathrm{C}$ in a miVac sample Duo concentrator. The dried extract was redissolved in water and successively extracted with diethyl-ether to remove the pigments, followed by extraction of saponins with saturated n-butanol. The n-butanol extracts were combined and dried under reduced pressure using a rotary evaporator (Buchi Rotavapor R-100, BÜCHI Labortechnik AG, Flawil, Switzerland). The dried extract was redissolved in aqueous methanol $80 \%(v / v)$ and subjected to the Vanillin- $\mathrm{H}_{2} \mathrm{SO}_{4}$ assay [31,32], using a Sunrise microplate reader at $540 \mathrm{~nm}$. Oleanolic acid $(0-0.5 \mathrm{~g} / \mathrm{L})$ was used to prepare an external calibration curve. Total saponins were expressed as $\mathrm{mg}$ of oleanolic acid equivalents (OE) per $100 \mathrm{~g}$ of sample.

\subsubsection{Antimicrobial Activity}

Powdered samples $(1 \mathrm{~g})$ were extracted 3 times with water or methanol in a sonication bath (30 min, rt). The supernatants were combined after centrifugation and evaporated at $60^{\circ} \mathrm{C}$ and $40{ }^{\circ} \mathrm{C}$ for water and methanolic extracts, respectively, using a miVac sample Duo concentrator. Aqueous methanol $20 \%(v / v)$ was used to freshly reconstitute the extract precipitates. Well diffusion assay followed the method described previously by Phan et al. [21] was applied to test the antimicrobial activity against Staphylococcus aureus, a Gram-positive bacteria; Escherichia coli, a Gram-negative bacteria and Candida albicans, a fungi. Penicillin and streptomycin (1 g) (Gibco, Life Technologies, Scoresby, Australia) and $10 \mu \mathrm{g}$ fluconazole (Sigma-Aldrich) were used as antibacterial and antifungal controls, respectively. Aqueous methanol $20 \%(v / v)$ was also included in the assay to evaluate the effect of solvent on microbial growth. The agar plates were incubated at $37^{\circ} \mathrm{C}$ for $24 \mathrm{~h}$ or $48 \mathrm{~h}$ (depending on growth), and the inhibition zones formed around the wells were recorded. The results were expressed as strong $(>13 \mathrm{~mm})$, moderate $(6-12 \mathrm{~mm})$, weak $(\geq 5 \mathrm{~mm})$ or no inhibitory activity $(<5 \mathrm{~mm})$ [33]. 


\subsubsection{Statistical Analysis}

A one-way analysis of variance (ANOVA), using Minitab 17 for Windows (Minitab, Inc., State College, PA, USA), was employed to test the variances of measurements. A $p$-value of 0.05 or less was considered as statistically significant. Pearson's correlation coefficient analysis was also applied to test correlations between bioactive compounds and bioactivities.

\section{Results and Discussion}

\subsection{Proximate, Minerals and Trace Elements}

\subsubsection{Proximate}

The proximate results showed that the predominant nutritional components of P. angustifolium are carbohydrates and dietary fiber, followed by low amounts of protein and fat (Table 1). Comparing between the two growing conditions (wild vs. cultivated), protein and carbohydrate contents were higher in the cultivated sample ( $7.2 \%$ vs. $10.6 \%$ and $26.6 \%$ vs. $31.3 \%$, respectively). In contrast, the wild sample contained more fat $(4.6 \%$ vs. $3.4 \%)$ and ash $(11.2 \%$ vs. $9.6 \%)$ than the cultivated one. The slight difference in the proximate composition probably reflects the potential effect of different growing conditions on the biosynthesis of nutritional components in P. angustifolium.

According to Food Standards Australia and New Zealand [34], if a serving of food contains at least 4 to $7 \mathrm{~g}$ of dietary fiber, it can be considered as a good to excellent source of dietary fiber. Based on this, P. angustifolium is a good source of dietary fiber (43.3-45.2\% DW; Table 1) with a recommended serving size of $10 \mathrm{~g}$ powder per day (suggested by Gumby Gumby, Ltd.). Furthermore, a relative high content of ash could be determined (9.6-11.2\% DW), indicating the presence of considerable concentrations of inorganic elements in this plant. Hence, it is necessary to determine minerals and trace elements to understand their nutritional significance in this plant.

Table 1. Proximate composition of P. angustifolium whole branch samples collected in Queensland.

\begin{tabular}{cccc}
\hline \multirow{2}{*}{ Proximate Composition } & QLD_Wild_WB & QLD_Cul_WB \\
\cline { 2 - 4 } & Protein & Quantity (g/100 g DW) ${ }^{*}$ \\
\hline \multirow{4}{*}{ Fat } & Total fat content & 7.2 & 10.6 \\
& Saturated fatty acids & 4.6 & 3.4 \\
& Monounsaturated fatty acids & 0.4 & 0.9 \\
& Polyunsaturated fatty acids & 2.4 & 0.2 \\
& Trans fatty acids & $<0.01$ & 2.3 \\
\multirow{2}{*}{ Carbohydrate } & Total carbohydrate & 26.6 & $<0.01$ \\
& Soluble sugars & 6.3 & 31.3 \\
& Total dietary fiber & 45.2 & 9.5 \\
\hline \multirow{2}{*}{$\quad$ Moisture } & 5.2 & 1.7 \\
\hline & Dry matter & 94.8 & 98.3 \\
\hline & Ash & 11.2 & 9.6 \\
\hline
\end{tabular}

* Data present means of duplicate analysis with a measurement of uncertainty below 10\%; DW—dry weight.

\subsubsection{Minerals and Trace Elements}

Generally, there was a significant $(p<0.05)$ difference in minerals and trace elements between P. angustifolium leaves and stems, with the leaves possessing significantly $(p<0.05)$ higher levels of minerals and trace elements than the stems (Table 2). Furthermore, the environment had a significant impact on minerals and chemical elements, particularly $\mathrm{Ca}, \mathrm{Na}, \mathrm{K}, \mathrm{P}, \mathrm{Fe}, \mathrm{Al}, \mathrm{Ba}, \mathrm{Hg}$ and $\mathrm{Pb}(p<0.05$ between wild and cultivated samples). Only $\mathrm{Mg}$ and $\mathrm{Ni}$ were found at comparable levels in the 
wild and cultivated samples $(p>0.05)$. Several elements such as $\mathrm{Ag}$, $\mathrm{Sn}$ and $\mathrm{Sb}$ were detected at relatively low levels (below $0.05 \mathrm{mg} / \mathrm{kg}$ DW), whereas $\mathrm{Ca}, \mathrm{K}$ and Fe were found at relatively high levels which could be favorable in terms of their dietary intake (Table 2). For heavy metals, $\mathrm{Al}$ was found at the highest level among the heavy metals quantified, followed by $\mathrm{Cr}, \mathrm{Pb}, \mathrm{Cd}$ and $\mathrm{Hg}$, with the $\mathrm{Al}$ content being found almost five times higher in the wild compared to the cultivated sample ( $89 \mathrm{vs}$. $18 \mathrm{mg} / \mathrm{kg}$ DW; Table 2). The obtained results suggest that the levels of minerals and trace elements in P. angustifolium are affected by different growing conditions as well as botanical tissues.

Table 2. Minerals and trace elements of different P. angustifolium samples collected in Queensland.

\begin{tabular}{|c|c|c|c|c|c|c|}
\hline \multirow{2}{*}{\multicolumn{2}{|c|}{$\begin{array}{l}\text { Chemical } \\
\text { Elements }\end{array}$}} & QLD-Wild-WB & QLD-Cul-WB & QLD-Cul-Leaf & QLD-Cul-Stem & Nutritional Information \\
\hline & & \multicolumn{4}{|c|}{$\mathrm{mg} / \mathbf{k g ~ D W}{ }^{*}$} & \\
\hline \multirow{5}{*}{ Minerals } & $\mathrm{Ca}$ & $27,302 \pm 190 \mathrm{a}$ & $7879 \pm 99 c$ & $10,095 \pm 31 b$ & $3295 \pm 194 \mathrm{~d}$ & 1200 mg/day AI [35] \\
\hline & $\mathrm{K}$ & $15,403 \pm 8 d$ & $22,766 \pm 179 b$ & $26,180 \pm 120 a$ & $19,131 \pm 528 c$ & 4.7 g/day AI [35] \\
\hline & $\mathrm{Mg}$ & $2547 \pm 9 b$ & $2590 \pm 21 b$ & $3284 \pm 10 \mathrm{a}$ & $989 \pm 43 c$ & 350 mg/day EAR [35] \\
\hline & $\mathrm{Na}$ & $878 \pm 3 c$ & $1161 \pm 5 b$ & $2083 \pm 15 a$ & $686 \pm 19 d$ & 1300 mg/day AI [35] \\
\hline & $\mathrm{P}$ & $1194 \pm 14 \mathrm{~d}$ & $2669 \pm 31 b$ & $2844 \pm 17 \mathrm{a}$ & $2286 \pm 37 c$ & 700 mg/day AI [35] \\
\hline \multirow{21}{*}{$\begin{array}{l}\text { Trace } \\
\text { elements }\end{array}$} & $\mathrm{B}$ & $68 \pm 1.0 \mathrm{a}$ & $48 \pm 0.6 c$ & $57.7 \pm 0.6 b$ & $16.7 \pm 1.0 \mathrm{~d}$ & - \\
\hline & $\mathrm{Al}$ & $89 \pm 4.4 \mathrm{a}$ & $18 \pm 0.6 c$ & $28.3 \pm 0.2 b$ & $7.5 \pm 0.1 \mathrm{~d}$ & $1.0 \mathrm{mg} / \mathrm{kg} \mathrm{BW} /$ week TWI [36] \\
\hline & $\mathrm{V}^{* *}$ & $0.14 \mathrm{a}$ & $0.04 \mathrm{c}$ & $0.05 \mathrm{~b}$ & $0.02 \mathrm{~d}$ & - \\
\hline & $\mathrm{Cr} * *$ & $0.33 \mathrm{a}$ & $0.11 \mathrm{~b}$ & $0.16 \mathrm{~b}$ & $0.14 \mathrm{~b}$ & 35 g/day AI [35] \\
\hline & Mn & $41.7 \pm 0.6 \mathrm{~b}$ & $39.7 \pm 0.6 c$ & $60.3 \pm 0.6 a$ & $12.3 \pm 0.6 \mathrm{~d}$ & 2.3 mg/day AI [35] \\
\hline & $\mathrm{Fe}$ & $116.7 \pm 5.8 \mathrm{a}$ & $48.3 \pm 1.0 \mathrm{~b}$ & $56 \pm 0.1 b$ & $17 \pm 1.2 \mathrm{c}$ & 8 mg/day RDA [35] \\
\hline & Co $* *$ & $0.1 \mathrm{a}$ & $0.05 \mathrm{~b}$ & $0.05 \mathrm{~b}$ & $0.02 \mathrm{c}$ & - \\
\hline & $\mathrm{Ni}$ & $0.9 \pm 0.1 b$ & $1.1 \pm 0.1 b$ & $1.57 \pm 0.1 \mathrm{a}$ & $1 \pm 0.1 b$ & - \\
\hline & $\mathrm{Cu}$ & $8.1 \pm 0.1 b$ & $8.9 \pm 0.1 \mathrm{a}$ & $6.8 \pm 0.1 c$ & $7.6 \pm 0.2 \mathrm{~d}$ & 900 g/day AI [35] \\
\hline & $\mathrm{Zn}$ & $57 \pm 1.0 \mathrm{c}$ & $62 \pm 0.1 b$ & $76.7 \pm 1.2 \mathrm{a}$ & $19.7 \pm 1.0 \mathrm{~d}$ & $11 \mathrm{mg} /$ day RDA [35] \\
\hline & As ** & $0.03 \mathrm{c}$ & $0.04 \mathrm{~b}$ & $0.06 \mathrm{a}$ & $0.02 \mathrm{~d}$ & $\begin{array}{c}128 \mu \mathrm{g} / \text { week for a } 60 \mathrm{~kg} \mathrm{BW} \\
\text { TWI [37] }\end{array}$ \\
\hline & $\mathrm{Se}^{* *}$ & $0.06 \mathrm{~b}$ & $0.08 \mathrm{a}$ & $0.08 \mathrm{a}$ & $0.04 \mathrm{c}$ & $55 \mu \mathrm{g} /$ day AI [35] \\
\hline & $\mathrm{Sr}$ & $140 \pm 0.1 \mathrm{a}$ & $47.3 \pm 0.6 \mathrm{~b}$ & $57.7 \pm 0.4 b$ & $32 \pm 0.6 \mathrm{~d}$ & - \\
\hline & Mo ** & $0.2 \mathrm{c}$ & $0.7 \mathrm{~b}$ & $0.8 \mathrm{a}$ & $0.2 \mathrm{c}$ & 45 g/day AI [35] \\
\hline & $\mathrm{Ag}$ & $<0.01$ & $<0.01$ & $<0.01$ & $<0.01$ & - \\
\hline & $\mathrm{Cd}^{* *}$ & $0.05 \mathrm{c}$ & $0.06 \mathrm{~b}$ & $0.07 \mathrm{a}$ & $0.06 \mathrm{~b}$ & $2.5 \mu \mathrm{g} / \mathrm{kg}$ BW/week TWI [38] \\
\hline & Sn & $<0.05$ & $<0.05$ & $<0.05$ & $<0.05$ & - \\
\hline & $\mathrm{Sb}$ & $<0.01$ & $<0.01$ & $<0.01$ & $<0.01$ & - \\
\hline & $\mathrm{Ba}$ & $36 \pm 0.3 a$ & $3.3 \pm 0.1 c$ & $4.0 \pm 0.2 \mathrm{~b}$ & $3.4 \pm 0.1 \mathrm{c}$ & - \\
\hline & $\mathrm{Hg} * *$ & $0.03 \mathrm{~b}$ & $0.05 \mathrm{a}$ & $0.01 \mathrm{c}$ & $<0.01$ & 5 g/kg BW/week TWI [39] \\
\hline & $\mathrm{Pb} * *$ & $0.12 \mathrm{a}$ & $0.06 \mathrm{c}$ & $0.08 \mathrm{bc}$ & $0.09 \mathrm{~b}$ & $25 \mu \mathrm{g} / \mathrm{kg}$ BW/week TWI [39] \\
\hline
\end{tabular}

* Data present means \pm SD $(n=3) ;{ }^{* *} \mathrm{SD} \leq 0.01$; Different letters at the same row indicate significant differences among the samples at $\alpha=0.05$; DW-dry weight; (-) - not available; RDA-recommended dietary allowance, $\mathrm{AI}$-adequate intake, EAR—estimated average requirement; BW—body weight; TWI—tolerable weekly intake.

\subsection{Vitamins}

\subsubsection{Non-Folate B Vitamins}

$B$ vitamins are crucial in many metabolic and physiological processes and can act as coenzymes in the energy metabolism (vitamins B1, B2, B3, B5 and B7), production of new cells (vitamins B6 and $\mathrm{B} 12$ ), protein metabolism (vitamin B6), and are essential for a functioning nervous system (vitamins B1, B3 and B12) [40]. Table 3 shows that only vitamins B2, B3, B5 and B6 could be quantified in the P. angustifolium whole branch sample (59 to $1300 \mu \mathrm{g} / 100 \mathrm{~g}$ DW) and vitamins B1, B7 and B12 were only found in traces $(<5 \mu \mathrm{g} / 100 \mathrm{~g}$ DW). Vitamin B3 was the highest among the analyzed B vitamins. Similar to the proximate composition, the cultivated sample contained more B vitamins (B2, B3 and B5) than the wild sample. Only vitamin B6 was higher in the wild sample. The recommended dietary intakes (RDI) for the analyzed B vitamins are also included in Table 3 for reference and extrapolation. 
Table 3. Selected B vitamins in P. angustifolium whole branch samples collected in Queensland.

\begin{tabular}{|c|c|c|c|}
\hline \multirow{2}{*}{ Vitamin } & QLD-Wild-WB & QLD-Cul-WB & \multirow{2}{*}{ Nutrition Information [34] } \\
\hline & \multicolumn{2}{|c|}{ Quantity (per 100 g DW) * } & \\
\hline B1 (Thiamin) & $<5 \mu \mathrm{g}$ & $<5 \mu \mathrm{g}$ & 1.1-1.2 mg/day RDI \\
\hline B2 (Riboflavin) & $<5 \mu \mathrm{g}$ & $73 \mu \mathrm{g}$ & 1.6 mg/day RDI \\
\hline B3 (Niacin) & $840 \mu \mathrm{g}$ & $1300 \mu \mathrm{g}$ & $14-16$ mg/day RDI \\
\hline B5 (Pantothenic acid) & $<5 \mu \mathrm{g}$ & $300 \mu \mathrm{g}$ & 4-6 mg/day RDI \\
\hline B6 (Pyridoxine) & $180 \mu \mathrm{g}$ & $59 \mu \mathrm{g}$ & 1.7 mg/day RDI \\
\hline B7 (Biotin) & $<5 \mu \mathrm{g}$ & $<5 \mu \mathrm{g}$ & 25-30 g/day RDI \\
\hline B12 (Cyanocobalamin) & $<5 \mu \mathrm{g}$ & $<5 \mu \mathrm{g}$ & 2.4 g/day RDI \\
\hline
\end{tabular}

* Data present means of duplicate analysis with a measurement of uncertainty below $10 \%$; DW—dry weight; RDI-recommended dietary intake for adults;

\subsubsection{Vitamin C}

Figure 2A shows that the cultivated leaf sample had the highest $(p<0.05)$ vitamin $\mathrm{C}$ content (137 mg/100 g DW) among the samples tested, followed by the whole branch and the stem samples. Ascorbic acid was not detectable (LOD $=0.1 \mathrm{ppm}$ ) in the P. angustifolium leaves collected from the wild in SA (SA-Wild-Leaf; Figure 2A). Regarding the impact of growing conditions, the wild samples had significantly $(p<0.05)$ lower vitamin C levels than the cultivated samples collected in QLD. The results reflect not only the importance of growing conditions and location, but also the drying procedure and sample treatment, which are critical in preserving vitamin C. The samples collected from the wild, both in SA and QLD, were air-dried, whereas the cultivated samples were freeze-dried, which is a very mild preservation procedure. Vitamin $C$ found in the cultivated leaf sample was double the amount of that reported in green tea leaf powder $(60 \mathrm{mg} / 100 \mathrm{~g}$ DW [41]).
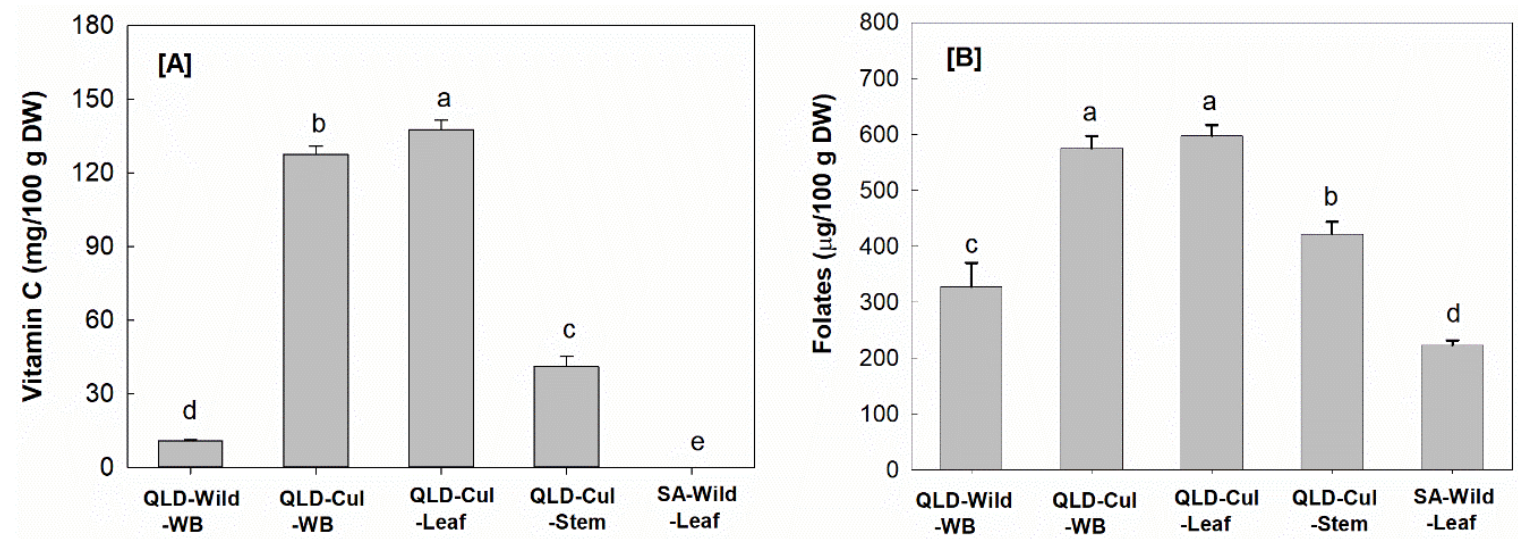

Figure 2. Contents of vitamin C (A) and folates (B) in the studied P. angustifolium samples; Data present means $\pm \mathrm{SD}(n=3)$; Different letters indicate significant differences at $\alpha=0.05$; RDI for vitamin $\mathrm{C}$ and folates are reported at $45 \mathrm{mg} /$ day and $400 \mu \mathrm{g} /$ day for adults, respectively [34].

\subsubsection{Folates}

Folates were found at moderate levels in the P. angustifolium samples following the order: QLD-Cul-Leaf $>$ QLD-Cul-WB $>$ QLD-Cul-Stem $>$ QLD-Wild-WB $>$ SA-Wild-Leaf (Figure 2B). $5-\mathrm{CH}_{3}-\mathrm{H}_{4}$ folate, the biologically active folate form, was the main folate vitamer found in the studied P. angustifolium samples (data not shown). Among the analyzed tissues, the leaves had a significantly $(p<0.05)$ higher folate content than the stem, but no difference $(p>0.05)$ could be observed between the leaves and the whole branch samples. Similar to vitamin C (Figure 2A), the total folate content of the leaves collected in SA was the lowest $(p<0.05)$ among the samples studied (Figure 2B), indicating the impact of the geographic location and/or sample treatment. The results also showed that the levels of folate in P. angustifolium (222-597 $\mu \mathrm{g} / 100 \mathrm{~g}$ DW, equivalent to 74-220 $\mu \mathrm{g} / 100 \mathrm{~g}$ FW, considering a 
moisture content of 63\%) are comparable to strawberry (59-153 $\mu \mathrm{g} / 100 \mathrm{~g}$ FW [41]), a popular dietary source of folate. However, it should be noted that the common serving size of P. angustifolium (max. $10 \mathrm{~g}$ powder) is much lower than that of strawberry fruit (144 g).

\subsection{Total Phenolic Content (TPC)}

The TPC results (free and bound) ranged from 730 to $4075 \mathrm{mg} \mathrm{GAE} / 100 \mathrm{~g}$ DW, depending on the plant tissue and geographic location, but was not affected by growing conditions (wild vs. cultivated) (Table 4). Furthermore, the free-TPC was considerably higher in all samples compared to the bound-TPC, as the free-TPC accounted for $>90 \%$ of total TPC. The stems had lower total TPC (free and bound) compared to the leaf samples but contained more $(p<0.05)$ bound TPC than the leaves; however, the bound TPC only contributed a minor proportion to the total TPC.

There was no difference $(p>0.05)$ in the TPC of the samples collected from the wild or cultivated in QLD. In contrast, different growing locations affected the TPC, as the wild leaves collected in SA possessed ca. 3-fold more $(p<0.05)$ total phenolics than the QLD samples (Table 4$)$. The results of the present study are similar to the reported TPC in leaves and twigs of other species belonging to the Pittosporaceae family, ranging from 2600 to $4090 \mathrm{mg}$ GAE/100 g DW [42-45]. However, compared to green tea leaf powder, a popular source of polyphenols, the TPC in the studied P. angustifolium samples was lower (730-4075 mg GAE/100 g DW vs. 6500-10,600 mg/100 g DW [46]).

Table 4. TPC, tannins and saponins in the studied P. angustifolium samples.

\begin{tabular}{|c|c|c|c|c|c|}
\hline \multirow{2}{*}{ Samples } & \multicolumn{3}{|c|}{ TPC (mg GAE/100 g DW) } & \multirow{2}{*}{$\begin{array}{c}\text { Total (Condensed) } \\
\text { Tannins } \\
\text { (mg CaE/100 g DW) }\end{array}$} & \multirow{2}{*}{$\begin{array}{c}\text { Total Saponins } \\
(\mathrm{mg} \mathrm{OE} / 100 \mathrm{~g} \mathrm{DW})\end{array}$} \\
\hline & Free & Bound & $\begin{array}{l}\text { Total Free } \\
\text { and Bound }\end{array}$ & & \\
\hline QLD_Wild_WB & $1306 \pm 41 b$ & $44.2 \pm 7.7 \mathrm{c}$ & $1350 \pm 47 b$ & $32 \pm 1.2 b$ & $3645 \pm 351 \mathrm{ab}$ \\
\hline QLD_Cul_WB & $1177 \pm 110 b$ & $44.6 \pm 2 c$ & $1222 \pm 112 b$ & $20 \pm 2.6 b c$ & $2869 \pm 343 b$ \\
\hline QLD_Cul_Leaf & $1254 \pm 59 b$ & $40.9 \pm 1.4 \mathrm{c}$ & $1295 \pm 60 b$ & $26.1 \pm 6.6 b c$ & $3871 \pm 157 \mathrm{a}$ \\
\hline QLD_Cul_Stem & $653 \pm 31 c$ & $76.3 \pm 7.8 \mathrm{~b}$ & $730 \pm 27 c$ & $15.9 \pm 3.2 c$ & $1590 \pm 223 c$ \\
\hline SA_Wild_Leaf & $3985 \pm 103 a$ & $90.9 \pm 4.2 \mathrm{a}$ & $4075 \pm 99 \mathrm{a}$ & $52 \pm 6.4 \mathrm{a}$ & $3250 \pm 319 a b$ \\
\hline
\end{tabular}

Data present means \pm SD $(n=3)$. Different letters at the same column indicate significant differences at $\alpha=0.05$.

\subsection{Total (Condensed) Tannins}

The total tannin content (TTC) in the studied P. angustifolium samples ranged from 15.9 to $52 \mathrm{mg}$ $\mathrm{CaE} / 100 \mathrm{~g}$ DW (Table 4) and was much lower than the TPC. Furthermore, the TTC was significantly $(p<0.05)$ affected by the geographical location, whereas growing conditions and different plant tissues did not affect $(p>0.05)$ the TTC. The QLD-grown samples showed a significantly $(p<0.05)$ lower TTC compared to the SA-grown sample. There is also a controversy in reporting tannins in Pittosporum species, probably due to the diversity of genotypes. For example, Amoo et al. [44] reported that condensed tannins were not detectable in leaves and twigs of P. viridiflorum collected in KwaZulu-Natal (South Africa), whereas Vesoul and Cock [14] and Momeni et al. [47] reported the presence of tannins (qualitative data only) in P. phylliraeoides collected in Queensland (Australia) and P. viridiflorum grown in Western Cameroon (Africa), respectively.

\subsection{Saponins}

Table 4 shows that $P$. angustifolium leaves and stems are rich sources of saponins, with levels up to $4000 \mathrm{mg} / 100 \mathrm{~g}$ equivalent to $4 \%$ on dry weight basis. Comparison with common saponin-rich foods such as legume seeds, including chickpeas ( $230 \mathrm{mg} / 100 \mathrm{~g}$ DW), kidney beans (410 mg/100 g DW) and soya beans $(650 \mathrm{mg} / 100 \mathrm{~g}$ DW) [48], the saponin content in the studied P. angustifolium samples is approximately 10-times higher. Contrary to the TTC and TPC, with SA leaves having significantly $(p<0.05)$ higher levels, the saponin content of P. angustifolium whole branch and leaves collected in QLD was higher than that of the SA leaves (trend only, $p>0.05$; Table 4). Interestingly, the saponin level 
in the leaf sample was double that of the stem (3870 vs. $1589 \mathrm{mg} \mathrm{OE} / 100 \mathrm{~g} \mathrm{DW}$ ), indicating a significant $(p<0.05)$ effect of the botanical tissue. There is limited information available regarding quantification of saponins in P. angustifolium as several previous studies only reported the presence of saponins in the Pittosporum genus by using qualitative screening tests without further quantification [11,14]. Recently, by applying NMR spectroscopy, mono- and bis-demosidic triterpene saponins as well as taraxastane-type triterpene saponins have been structurally identified as the main triterpenoid saponin compounds in P. angustifolium [8-10]. Further studies on profiling and quantification of individual saponins in this plant are necessary.

\subsection{Individual Phenolic Compounds}

Figure 3A,B presents the predominant phenolic compounds identified in the studied P. angustifolium samples (further details are summarized in Supplementary Table S2 \& Figure S1). In agreement with the TPC (Section 3.3), the total amount of free phenolic compounds was considerably higher than that of bound phenolics (689-3931 vs. 10.1-26.5 mg/100 g DW, data not shown), suggesting that the free polyphenols may be primarily responsible for potential biologic activities of P. angustifolium.
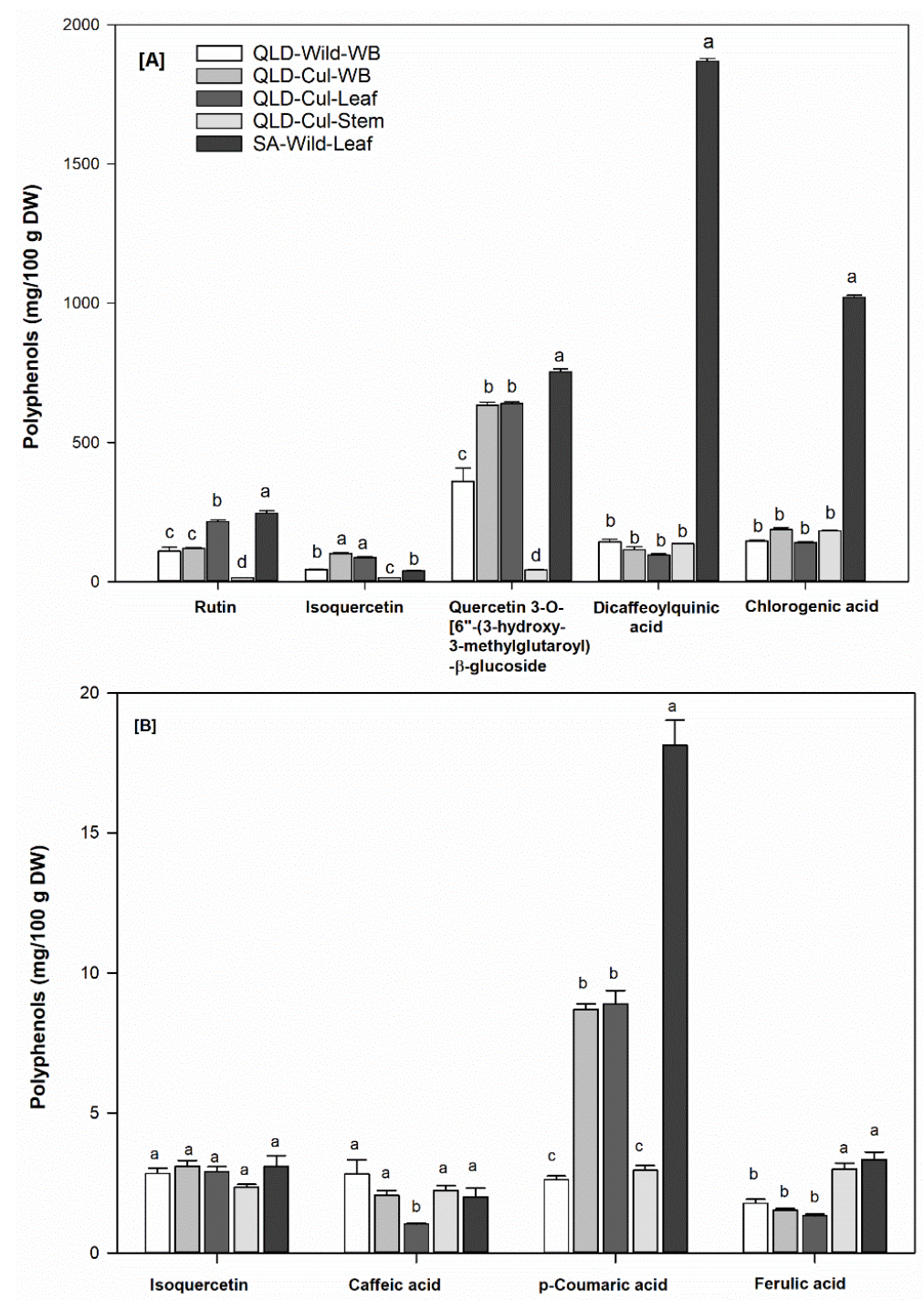

Figure 3. Free (A) and bound (B) phenolic compounds in the studied P. angustifolium samples; Data present means $\pm \mathrm{SD}(n=3)$; Different letters of individual phenolic compounds indicate significant differences at $\alpha=0.05$. 
However, all samples showed a similar phenolic profile, the concentrations of individual phenolic compounds varied depending on the extract (free or bound), botanical tissues, growing condition and location. For instance, the free extract was rich in flavonoids, whereas phenolic acids were predominant in the bound extract (Figure 3). While the stem had significantly $(p<0.05)$ lower levels of free phenolic acids and flavonoids than the leaves, the leaves had lower levels of bound phenolic compounds compared to the stem, except for p-coumaric acid. Similar to the TPC, a significantly $(p<0.05)$ higher amount of phenolic acids and flavonoids (free $>3$-fold and bound ca. 2-fold) was found in the SA leaves compared to the QLD grown samples (Figure 3), clearly indicating the effect of geographical location on individual polyphenols.

Previously, a number of studies have reported the presence of caffeic, ferulic and p-coumaric acids in methanolic extracts of $P$. tobira seeds [19] as well as rutin, isoquercitrin, isoquercitrinhydroxymethylglutaroyl- $\beta$-glucoside and dicaffeoylquinic acids in the leaves of P. angustifolium [12] (Figure 1), which support the findings of the present study as shown in Figure 3A,B. Interestingly, chlorogenic acid, which has not been previously reported in P. angustifolium, was also detected in the studied samples (Figure 3A).

\subsection{Carotenoids}

Lutein, zeaxanthin and $\beta$-carotene could be identified as the main carotenoids in the P. angustifolium samples (Figure 4 and Supplementary Table S3 \& Figure S2). Lutein was the predominant carotenoid ( $>70 \%$ of the total carotenoid content), followed by zeaxanthin or $\beta$-carotene (depending on the sample). The total carotenoid content varied from 1.8 to $21.8 \mathrm{mg} / 100 \mathrm{~g} \mathrm{DW}$, which is higher than that reported for sweet corn (3.7 mg/100 g DW [49]).

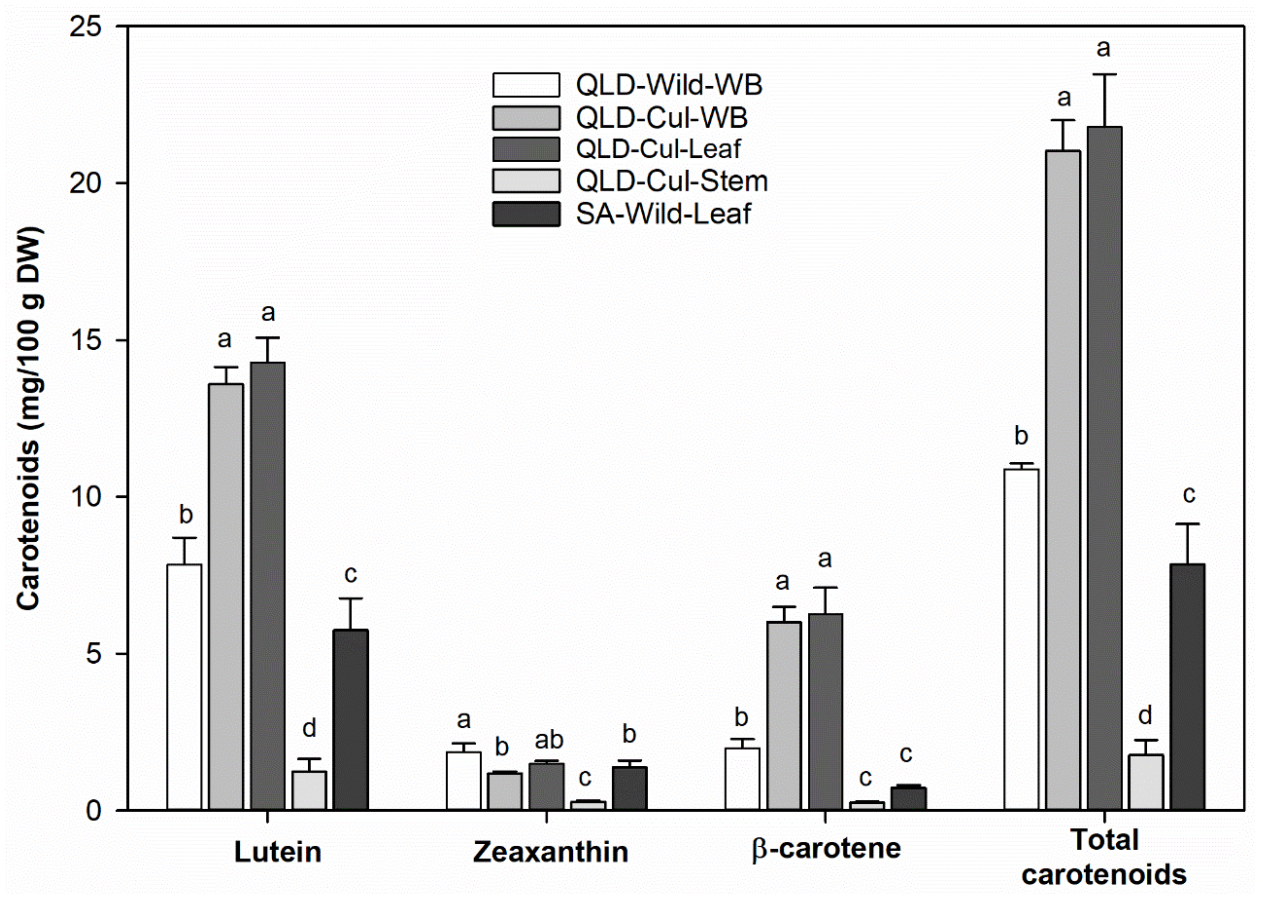

Figure 4. Carotenoids identified in the studied P. angustifolium samples. Data present means \pm SD $(n=3)$; Different letters of individual carotenoid compounds indicate significant differences at $\alpha=0.05$.

There was significant $(p<0.05)$ variation in carotenoid content between different botanical tissues. The stem had lower $(p<0.05)$ carotenoid levels than the leaves, suggesting that carotenoids are mainly synthesized and stored in the leaf tissue. An approximately 2-fold higher concentration of carotenoids (except for zeaxanthin) could be found in the cultivated sample compared to the wild samples collected from both QLD and SA. This is most likely due to differences in sample treatment 
and storage conditions (as also observed for vitamin C and folates). To the best of our knowledge, this is the first study reporting individual carotenoids in P. angustifolium.

\subsection{DPPH Radical-Scavenging Capacity}

The leaf sample, collected from the wild in SA, exhibited a significantly $(p<0.05)$ higher DPPH radical-scavenging capacity at 0.5 and $1 \mathrm{mg}$ powder $/ \mathrm{mL}$, followed by the QLD whole branch sample collected from the wild (QLD-Wild-WB) (Figure 5), which strongly correlates with the TPC and individual phenolic compounds. The cultivated samples showed significantly $(p<0.05)$ lower radical-scavenging capacity than the wild samples, except for the concentration of $2.5 \mathrm{mg}$ powder $/ \mathrm{mL}$. The results also showed that the extracts from the SA leaves $(0.5 \mathrm{~g}$ powder $/ \mathrm{mL})$ or from the QLD samples $(0.7-1 \mathrm{~g}$ powder $/ \mathrm{mL})$ collected either from the wild or cultivated exhibited a similar DPPH radical-scavenging capacity $\left(\mathrm{EC}_{50}\right)$ as $0.1 \mathrm{mg}$ ascorbic acid (Figure 5). However, the cultivated leaf sample contained more vitamin $\mathrm{C}$, folates and carotenoids than the samples collected from the wild (QLD and SA), more sample material was needed to reduce the initial DPPH radical concentration by $50 \%\left(E_{50}: 1 \mathrm{~g}\right.$ powder/mL QLD cultivated leaves vs. $0.7 \mathrm{~g}$ powder/mL QLD wild leaves or 0.5-g powder/mL SA wild leaves). This clearly indicates a possible correlation of DPPH radical-scavenging capacity with polyphenols, as a result of their electron transfer/hydrogen donating ability. The SA leaves had the highest levels of TPC and tannins, resulting in the highest DPPH radical-scavenging capacity. The Pearson's correlation coefficient test (Section 3.10) supports this interpretation.

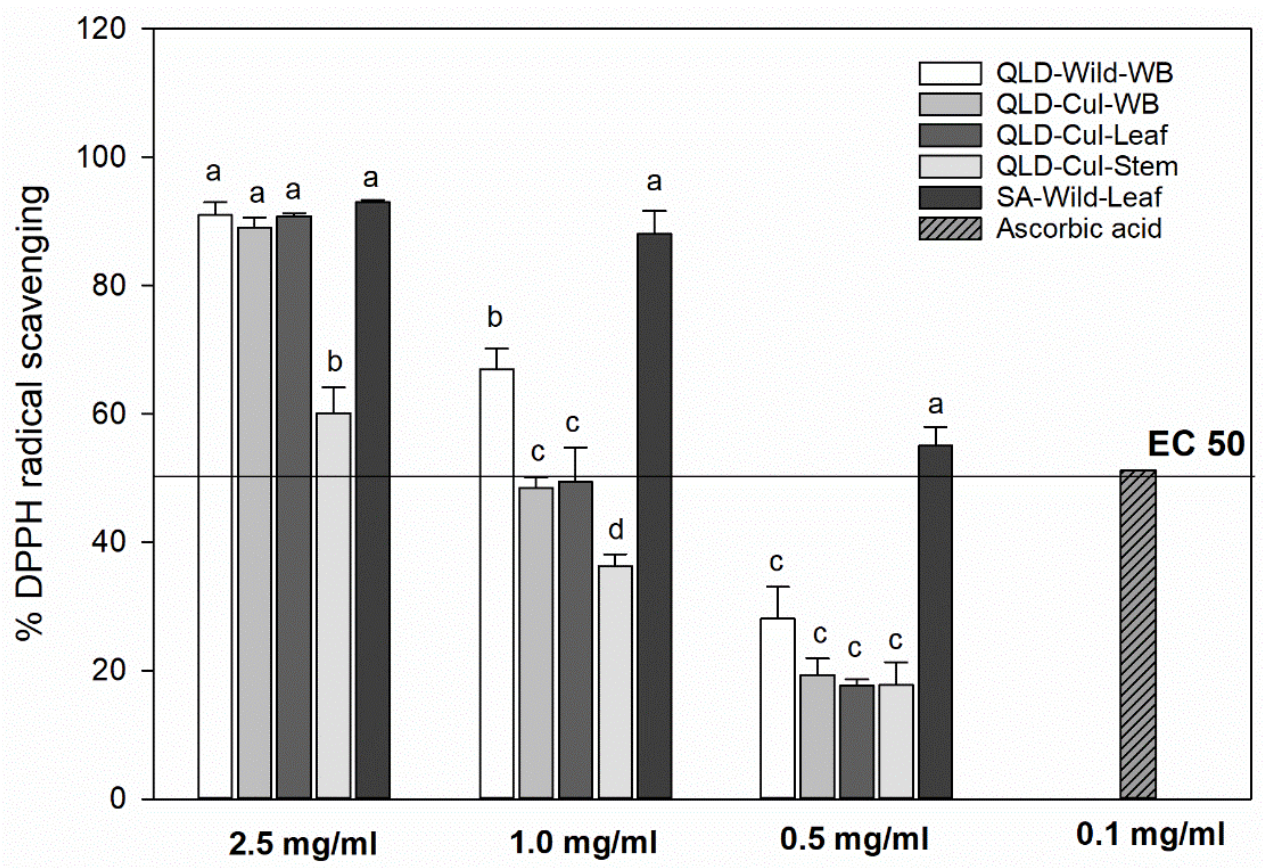

Figure 5. 2,2-diphenyl-1-picrylhydrazyl (DPPH) radical-scavenging capacity of P. angustifolium extracts. $\mathrm{EC}_{50}$ value is the amount/concentration of the sample extract or ascorbic acid necessary to scavenge/reduce the initial DPPH radical concentration by $50 \%$ (50\% effective concentration). Different letters within individual extract indicate significant differences at $\alpha=0.05$.

\subsection{Antimicrobial Susceptibility Test}

Both methanolic and water extracts of the P. angustifolium samples showed inhibition against C. albicans, with inhibition zones being similar to the standard antibiotic solution (Table 5). However, no inhibition against E. coli and S. aureus was observed, except for the SA leaves which showed a moderate inhibition to $S$. aureus. The observed inhibition zones varied from 12.8 to $26.9 \mathrm{~mm}$, suggesting a strong antimicrobial activity of the extracts from P. angustifolium against C. albicans. Although there was a substantial variation in bioactive compounds, depending on the botanical tissue, growing condition 
and geographical location, comparable antifungal activity was observed for all samples, except for the SA leaves, which showed higher antimicrobial activity (trend only, $p>0.05$ ) compared to the QLD grown samples (Table 5). Furthermore, the water extract of the QLD whole branch sample collected from the wild showed significantly lower (nearly 2-fold; $p<0.05$ ) inhibition compared to the cultivated sample, although those samples had similar levels of bioactive compounds. This suggests that the microbial inhibitory effect may be primarily driven by a synergistic effect of the polyphenol/bioactive compounds "complex" present in the extracts rather than a specific subclass or individual bioactive compound as previously hypothesized by Barbieri et al. [50].

A comparison between the two extraction methods showed that the water extract exhibited stronger antifungal activity than the methanolic extract, except for the QLD-Wild-WB sample (Table 5). Differences in the antimicrobial activity between the two extraction methods may be due to differences in the extraction efficiency resulting in higher or lower concentrations of specific bioactive compounds with antimicrobial activity (e.g., against $C$. albicans). The obtained results of antimicrobial activity are in agreement with the study of Vesoul and Cock [14], who previously reported a relatively low or no inhibitory effect of water and/or methanolic extracts of P. phylliraeoides against E. coli and S. aureus.

Table 5. Antimicrobial activity of the studied P. angustifolium samples.

\begin{tabular}{ccccccc}
\hline & \multicolumn{2}{c}{ E. coli } & \multicolumn{2}{c}{ S. aureus } & \multicolumn{2}{c}{ C. albicans } \\
\cline { 2 - 7 } Samples & $\begin{array}{c}\text { Water } \\
\text { Extraction }\end{array}$ & $\begin{array}{c}\text { MeOH } \\
\text { Extraction }\end{array}$ & $\begin{array}{c}\text { Water } \\
\text { Extraction }\end{array}$ & $\begin{array}{c}\text { MeOH } \\
\text { Extraction }\end{array}$ & $\begin{array}{c}\text { Water } \\
\text { Extraction }\end{array}$ & $\begin{array}{c}\text { MeOH } \\
\text { Extraction }\end{array}$ \\
\cline { 2 - 7 } & \multicolumn{7}{c}{ Inhibition Zone (mm) * } \\
\hline QLD-Wild-WB & - & - & - & - & $13.6 \pm 2.2 \mathrm{c}$ & $19.5 \pm 1.7 \mathrm{bc}$ \\
QLD-Cul-WB & - & - & - & - & $24.7 \pm 0.7 \mathrm{ab}$ & $20.6 \pm 0.6 \mathrm{ab}$ \\
QLD-Cul-Leaf & - & - & - & - & $23.1 \pm 1.6 \mathrm{ab}$ & $21.2 \pm 1.9 \mathrm{ab}$ \\
QLD-Cul-Stem & - & - & - & - & $24.0 \pm 0.8 \mathrm{ab}$ & $21.0 \pm 1.8 \mathrm{ab}$ \\
SA-Wild-Leaf & - & - & $12.8 \pm 0.9$ & - & $26.9 \pm 1.6 \mathrm{a}$ & $25.3 \pm 2.4 \mathrm{ab}$ \\
\hline Antibiotic/antifungal \\
control
\end{tabular}

$\left(^{*}\right)$ Data present means $\pm \mathrm{SD}(n=3) ;\left(^{* *}\right)$ antibiotic and antifungal control as stated in the method section; (-) No inhibition zone was observed. Different letters indicate significant differences among the samples at $\alpha=0.05$.

\subsection{Pearson's Correlation Analysis}

The results of Pearson's correlation test (Table 6) indicated a positive correlation $\left(R^{2}=0.64-0.92\right.$, $p<0.05$ ) between polyphenols (e.g., TPC, rutin, quercetin 3-O-[6"-(3-hydroxy-3-methylglutaroyl)$\beta$-glucoside], dicaffeoylquinic acid and tannins) and the DPPH radical-scavenging capacity. Saponins and polyphenols, particularly tannins, rutin and quercetin 3-O-[6"-(3-hydroxy-3-methylglutaroyl)$\beta$-glucoside], one of the main phenolic compounds present in the free form, showed a positive $\left(R^{2}=0.76-0.81, p<0.05\right)$ correlation with the antifungal activity. However, vitamin $C$ (another strong antioxidant), folates and carotenoids were negatively correlated with the DPPH radical-scavenging capacity and antimicrobial activity (Table 6). This may be due to the relatively low concentrations of these vitamins and pro-vitamins in the tested samples, which were most likely too low to show any significant effects in reducing the DPPH radicals or antimicrobial activity. The results of the Pearson's correlation test provided a general understanding on how bioactive compounds may contribute to the observed biologic effects of P. angustifolium. 
Table 6. Pearson's correlation coefficients between bioactive compounds, DPPH radical-scavenging capacity and antifungal activity.

\begin{tabular}{|c|c|c|c|c|c|}
\hline \multirow[b]{2}{*}{ Bioactive Compounds } & \multicolumn{3}{|c|}{ \% DPPH Free Radical-Scavenging } & \multicolumn{2}{|c|}{ C. albicans Inhibition } \\
\hline & $2.5 \mathrm{mg} / \mathrm{mL}$ & $1 \mathrm{mg} / \mathrm{mL}$ & $0.5 \mathrm{mg} / \mathrm{mL}$ & $\begin{array}{l}\text { Water Extract } \\
(0.5 \mathrm{mg} / \mathrm{mL})\end{array}$ & $\begin{array}{l}\text { MeOH Extract } \\
(0.5 \mathrm{mg} / \mathrm{mL})\end{array}$ \\
\hline TPC & $0.78^{* *}$ & $0.87 * * *$ & $0.92 * * *$ & 0.24 & $0.76 *$ \\
\hline Rutin & $0.76 * *$ & $0.69 *$ & $0.66 *$ & 0.57 & 0.64 \\
\hline Isoquercetin & -0.03 & -0.40 & -0.18 & -0.48 & -0.05 \\
\hline Quercetin & & & & & \\
\hline $\begin{array}{l}\text { 3-O-[6"-(3-hydroxy-3- } \\
\text { methylglutaroyl)- } \beta \text {-glucoside] }\end{array}$ & $0.71 * *$ & $0.65 *$ & $0.64 *$ & 0.60 & $0.81 *$ \\
\hline Dicaffeoylquinic acid & 0.48 & 0.58 & $0.60 *$ & 0.48 & 0.36 \\
\hline Chlorogenic acid & 0.36 & 0.45 & 0.41 & 0.57 & 0.48 \\
\hline Vitamin C & $-0.58 *$ & $-0.65 *$ & $-0.73 * *$ & -0.32 & -0.42 \\
\hline Folates & $-0.59 *$ & $-0.68 *$ & $-0.64 *$ & -0.36 & -0.36 \\
\hline Carotenoids & -0.07 & -0.10 & -0.21 & -0.55 & 0.048 \\
\hline Saponins & 0.26 & 0.37 & 0.26 & 0.79 * & 0.31 \\
\hline Tannins & $0.75 * *$ & $0.92 * * *$ & $0.83 * * *$ & 0.38 & 0.55 \\
\hline
\end{tabular}

Statistical significance at ${ }^{*}-p<0.05,{ }^{* *}-p<0.01$ and ${ }^{* * *}-p<0.001$

\section{Conclusions}

The present study, to the best of our knowledge, reports for the first time the proximate composition, minerals and trace elements, vitamins and carotenoids in P. angustifolium leaves and stems collected from the wild or cultivated. P. angustifolium leaves could be identified as a rich source of saponins and polyphenols, whereas carotenoids, tannins and vitamins (B and C) were present at lower levels. The results indicate that multiple factors, such as growing condition, geographic location and different botanical tissues, can have a significant effect on the bioactive compounds in P. angustifolium and subsequently its bioactivity. However, further studies with more samples (total number and replicates), different seasons and growing locations, are strongly recommended to substantiate the results of the present study. The finding of the Pearson's correlation suggests that only polyphenols have a significant correlation with the DPPH radical-scavenging capacity, whereas the antifungal activity against $C$. albicans was positively correlated with both polyphenols and saponins. This study further confirms the relationship between (phyto) chemicals and biologic properties in P. angustifolium, suggesting potential applications of this Australian indigenous plant as a functional (food) ingredient and/or a natural fungicide.

Supplementary Materials: The following are available online at http://www.mdpi.com/2304-8158/9/7/887/s1: Figure S1: Representative ion chromatograms and fragmentation patterns of detected phenolic compounds in P. angustifolium. Figure S2: Representative ion chromatograms and fragmentation patterns of detected carotenoids in P. angustifolium. Table S1: Details of chromatographic analysis of carotenoids, polyphenols, ascorbic acid and folates [51]. Table S2: Characterization of phenolic compounds detected in P. angustifolium by UHPLC-ESI-MS/MS scanning at negative mode. Table S3: Characterization of carotenoid compounds detected in P. angustifolium by UHPLC-APCI-MS/MS scanning at positive mode.

Author Contributions: Conceptualization, A.D.T.P., M.E.N. and Y.S.; methodology, A.D.T.P., M.C., U.T. and H.T.H.; software, A.D.T.P.; validation, A.D.T.P., M.E.N. and Y.S.; formal analysis, A.D.T.P., M.C. and U.T.; data curation, A.D.T.P.; writing-original draft preparation, A.D.T.P.; review and editing, M.C., H.T.H., U.T., M.E.N. and Y.S.; supervision, M.E.N. and Y.S.; funding acquisition, Y.S. All authors have read and agreed to the published version of the manuscript.

Funding: This research was funded by the Commonwealth Department of Industry and Science via the Innovation Connection Grant Scheme and The Australian Research Council (ARC) Industrial Transformation Training Centre for Uniquely Australian Foods (Grant number: IC180100045).

Acknowledgments: The authors acknowledge Ken Murray (Gumby Gumby Australia, Ltd.) for his support and collection of plant material. The authors acknowledge the Traditional Owners of the lands on which the $P$. angustifolium grows and respect the knowledge and experience the Traditional Owners hold regarding the care, harvest and use of these plants. 
Conflicts of Interest: The authors declare no conflict of interest.

\section{References}

1. Smith, T.; Gillespie, M.; Eckl, V.; Knepper, J.; Reynolds, C.M. Herbal Supplement Sales in US Increase by $9.4 \%$ in 2018. HerbalGram 2019, 123, 62-73.

2. Cayzer, L.W.; Crisp, M.D.; Telford, I. Revision of Pittosporum (Pittosporaceae) in Australia. Aust. Syst. Bot. 2000, 13, 845-902. [CrossRef]

3. Lassack, E.V.; Mccarthy, T. Australian Medicinal Plants; Methuen Australia: Sydney, Australia, 1983; p. 240.

4. Latz, P. Bushfires and Bushtucker: Aboriginal Plant Use in Central Australia; Iad Press: Oxford, UK, 1995.

5. Cock, I.; Winnett, V.; Sirdaarta, J.; Matthews, B. The potential of selected Australian medicinal plants with anti-Proteus activity for the treatment and prevention of rheumatoid arthritis. Pharmacogn. Mag. 2015, 11, S190. [CrossRef] [PubMed]

6. Madikizela, B.; McGaw, L.J. Pittosporum viridiflorum Sims (Pittosporaceae): A review on a useful medicinal plant native to South Africa and tropical Africa. J. Ethnopharmacol. 2017, 205, 217-230. [CrossRef]

7. Errington, S.G.; Jefferies, P.R. Triterpenoid sapogenins of Pittosporum phillyraeoides. Phytochemistry 1988, 27, 543-545. [CrossRef]

8. Backer, C.; Jenett-Siems, K.; Siems, K.; Wurster, M.; Bodtke, A.; Chamseddin, C.; Crusemann, M.; Lindequist, U. Triterpene glycosides from the leaves of Pittosporum angustifolium. Planta Med. 2013, 79, 1461-1469. [CrossRef]

9. Backer, C.; Jenett-Siems, K.; Siems, K.; Wurster, M.; Bodtke, A.; Niedermeyer, T.H.J.; Lindequist, U. New Mono and Bisdesmosidic Triterpene Glycosides from Pittosporum angustifolium Lodd. Z. Fur Nat. Sect. B A J. Chem. Sci. 2014, 69, 1026-1044. [CrossRef]

10. Backer, C.; Jenett-Siems, K.; Siems, K.; Niedermeyer, T.H.J.; Wurster, M.; Bodtke, A.; Lindequist, U. Taraxastane-type triterpene saponins isolated from Pittosporum angustifolium Lodd. Z. Fur Nat. Sect. B A J. Chem. Sci. 2015, 70, 403-408. [CrossRef]

11. Sadgrove, N.; Jones, G. Chemical and biological characterisation of solvent extracts and essential oils from leaves and fruit of two Australian species of Pittosporum (Pittosporaceae) used in aboriginal medicinal practice. J. Ethnopharmacol. 2013, 145, 813-821. [CrossRef]

12. Bäcker, C.; Jenett-Siems, K.; Bodtke, A.; Lindequist, U. Polyphenolic compounds from the leaves of Pittosporum angustifolium. Biochem. Syst. Ecol. 2014, 55, 101-103. [CrossRef]

13. Manase, M.J.; Mitaine-Offer, A.-C.; Miyamoto, T.; Tanaka, C.; Delemasure, S.; Dutartre, P.; Lacaille-Dubois, M.-A. New triterpenoid estersaponins from the root barks of Pittosporum verticillatum subsp. verticillatum and evaluation of cytotoxicities. Fitoterapia 2013, 91, 231-235. [CrossRef] [PubMed]

14. Vesoul, J.; Cock, I. An examination of the medicinal potential of Pittosporum phylliraeoides: Toxicity, antibacterial and antifungal activities. Pharmacogn. Commun. 2011, 1, 8-17. [CrossRef]

15. Association of Official Analytical Chemists. Official Methods of Analysis; Association of Official Analytical Chemists: Washington, DC, USA, 1997.

16. Association of Official Analytical Chemists. Official Methods of Analysis; Association of Official Analytical Chemists: Washington, DC, USA, 1999.

17. Association of Official Analytical Chemists. Official Methods of Analysis; Association of Official Analytical Chemists: Washington, DC, USA, 2000.

18. Akter, S.; Netzel, M.E.; Fletcher, M.T.; Tinggi, U.; Sultanbawa, Y. Chemical and Nutritional Composition of Terminalia ferdinandiana (Kakadu Plum) Kernels: A Novel Nutrition Source. Foods 2018, 7, 60. [CrossRef] [PubMed]

19. Rjeibi, I.; Ncib, S.; Ben Saad, A.; Souid, S. Evaluation of nutritional values, phenolic profile, aroma compounds and biological properties of Pittosporum tobira seeds. Lipids Health Dis. 2017, 16, 206. [CrossRef]

20. Adom, K.K.; Liu, R.H. Antioxidant Activity of Grains. J. Agric. Food Chem. 2002, 50, 6182-6187. [CrossRef] [PubMed]

21. Phan, A.D.T.; Chaliha, M.; Sultanbawa, Y.; Netzel, M.E. Nutritional Characteristics and Antimicrobial Activity of Australian Grown Feijoa (Acca sellowiana). Foods 2019, 8, 376. [CrossRef]

22. Djuikwo, V.; Ejoh, A.; Inocent, G.; Mbofung, C.; Tanumihardjo, S. Determination of Major Carotenoids in Processed Tropical Leafy Vegetables Indigenous to Africa. Food Nutr. Sci. 2011, 2, 9. [CrossRef] 
23. Gupta, P.; Sreelakshmi, Y.; Sharma, R. A rapid and sensitive method for determination of carotenoids in plant tissues by high performance liquid chromatography. Plant Methods. 2015, 11, 5. [CrossRef]

24. Striegel, L.; Chebib, S.; Netzel, M.E.; Rychlik, M. Improved Stable Isotope Dilution Assay for Dietary Folates Using LC-MS/MS and Its Application to Strawberries. Front. Chem. 2018, 6, 11. [CrossRef]

25. Campos, F.M.; Ribeiro, S.M.R.; Della Lucia, C.M.; Pinheiro-Sant'Ana, H.M.; Stringheta, P.C. Optimization of methodology to analyze ascorbic and dehydroascorbic acid in vegetables. Química. Nova 2009, 32, 87-91. [CrossRef]

26. Spinola, V.; Mendes, B.; Camara, J.S.; Castilho, P.C. An improved and fast UHPLC-PDA methodology for determination of L-ascorbic and dehydroascorbic acids in fruits and vegetables. Evaluation of degradation rate during storage. Anal. Bioanal. Chem. 2012, 403, 1049-1058. [CrossRef] [PubMed]

27. Singleton, V.L.; Rossi, J.A. Colorimetry of total phenolics with phosphomolybdic-phosphotungstic acid reagents. Am. J. Enol. Vitic. 1965, 16, 144-158.

28. Moore, J.; Yu, L. Methods for Antioxidant Capacity Estimation of Wheat and Wheat-Based Food Products. In Wheat Antioxidants; Yu, L., Ed.; John Wiley \& Sons, Inc.: Hoboken, NJ, USA, 2007. [CrossRef]

29. Karamac, M.; Kosinska, A.; Rybarczyk, A.; Amarowicz, R. Extraction and chromatographic separation of tannin fractions from tannin-rich plant material. Pol. J. Food Nutr. Sci. 2007, 57, 471-474.

30. Price, M.L.; Vanscoyoc, S.; Butler, L.G. Critical Evaluation of Vanillin Reaction as an Assay for Tannin in Sorghum Grain. J. Agric. Food Chem. 1978, 26, 1214-1218. [CrossRef]

31. Helaly, F.M.; Soliman, H.S.M.; Soheir, A.D.; Ahmed, A.A. Controlled release of migration of molluscicidal saponin from different types of polymers containing Calendula officinalis. Adv. Polym. Technol. 2001, 20, 305-311. [CrossRef]

32. Dini, I.; Tenore, G.C.; Dini, A. Saponins in Ipomoea batatas tubers: Isolation, characterization, quantification and antioxidant properties. Food Chem. 2009, 113, 411-419. [CrossRef]

33. Mosbah, H.; Louati, H.; Boujbiha, M.A.; Chahdoura, H.; Snoussi, M.; Flamini, G.; Ascrizzi, R.; Bouslema, A.; Achour, L.; Selmi, B. Phytochemical characterization, antioxidant, antimicrobial and pharmacological activities of Feijoa sellowiana leaves growing in Tunisia. Ind. Crop. Prod. 2018, 112, 521-531. [CrossRef]

34. Food Standards Australia and New Zealand. Available online: https://www.foodstandards.gov.au/Pages/ default.aspx (accessed on 15 April 2020).

35. Otten, J.; Hellwig, J.; Meyers, L. Dietary Reference Intakes: The Essential Guide to Nutrient Requirements; National Academies Press: Washington, DC, USA, 2006.

36. European Food Safety Authority. Safety of aluminium from dietary intake-Scientific Opinion of the Panel on Food Additives, Flavourings, Processing Aids and Food Contact Materials (AFC). EFSA J. 2008, 754, 1-34. [CrossRef]

37. Leblanc, J.-C.; Malmauret, L.; GuÉrin, T.; Bordet, F.; Boursier, B.; Verger, P. Estimation of the dietary intake of pesticide residues, lead, cadmium, arsenic and radionuclides in France. Food Addit. Contam. 2000, 17, 925-932. [CrossRef]

38. EFSA Panel on Contaminants in the Food Chain(CONTAM). Statement on tolerable weekly intake for cadmium. EFSA J. 2011, 9, 1975. [CrossRef]

39. Cheung Chung, S.W.; Kwong, K.P.; Yau, J.C.; Wong, W.W. Dietary exposure to antimony, lead and mercury of secondary school students in Hong Kong. Food Addit. Contam. 2008, 25, 831-840. [CrossRef] [PubMed]

40. Zhang, Y.; Zhou, W.-E.; Yan, J.-Q.; Liu, M.; Zhou, Y.; Shen, X.; Ma, Y.-L.; Feng, X.-S.; Yang, J.; Li, G.-H. A Review of the Extraction and Determination Methods of Thirteen Essential Vitamins to the Human Body: An Update from 2010. Molecules 2018, 23, 1484. [CrossRef] [PubMed]

41. United States Department of Agriculture. USDA Food Composition Databases. 2019. Available online: https://ndb.nal.usda.gov/ndb/ (accessed on 15 April 2020).

42. Shieh, P.; Govindasamy, A.; Kuo, D. Evaluation of antioxidant polyphenols in Taiwan's medicinal plants. Asian J. Chem. 2009, 21, 5556-5562.

43. Wandji, B.A.; Bomba, F.D.T.; Awouafack, M.D.; Nkeng-Efouet, P.A.; Kamanyi, A.; Nguelefack, T.B. Antinociceptive effects of the aqueous and methanol extracts of the leaves of Pittosporum mannii Hook. F. (Pittosporaceae) in mice. J. Ethnopharmacol. 2016, 187, 224-231. [CrossRef] [PubMed]

44. Amoo, S.O.; Aremu, A.O.; Moyo, M.; Van Staden, J. Antioxidant and acetylcholinesterase-inhibitory properties of long-term stored medicinal plants. BMC Complement. Altern. Med. 2012, 12, 87. [CrossRef] [PubMed] 
45. Olaokun, O.; Mkolo, N.; Mogale, M.; King, P. Phytochemical Screening, Antioxidant, Anti-inflammatory and Glucose Utilization Activities of Three South African Plants Used Traditionally to Treat Diseases. Biol. Med. 2017, 9, 2. [CrossRef]

46. Khokhar, S.; Magnusdottir, S.G.M. Total Phenol, Catechin, and Caffeine Contents of Teas Commonly Consumed in the United Kingdom. J. Agric. Food Chem. 2002, 50, 565-570. [CrossRef]

47. Momeni, J.; Djialeu Ntchatchoua, W.P.; Akam, F.M.T.; Ngassoum, M.B. Antioxidant activities of some cameroonian plants extracts used in the treatment of intestinal and infectious diseases. Indian J. Pharm. Sci. 2010, 72, 140-144. [CrossRef]

48. Savage, G.P. Saponins. In Encyclopedia of Food Sciences and Nutrition, 2nd ed.; Caballero, B., Ed.; Academic Press: Oxford, UK, 2003; pp. 5095-5098. [CrossRef]

49. O'Hare, T.J.; Fanning, K.J.; Martin, I.F. Zeaxanthin biofortification of sweet-corn and factors affecting zeaxanthin accumulation and colour change. Arch. Biochem. Biophys. 2015, 572, 184-187. [CrossRef]

50. Barbieri, R.; Coppo, E.; Marchese, A.; Daglia, M.; Sobarzo-Sánchez, E.; Nabavi, S.F.; Nabavi, S.M. Phytochemicals for human disease: An update on plant-derived compounds antibacterial activity. Microbiol. Res. 2017, 196, 44-68. [CrossRef]

51. Rivera, S.M.; Christou, P.; Canela-Garayoa, R. Identification of carotenoids using mass spectrometry. Mass Spectrom. Rev. 2014, 33, 353-372. [CrossRef] [PubMed]

(C) 2020 by the authors. Licensee MDPI, Basel, Switzerland. This article is an open access article distributed under the terms and conditions of the Creative Commons Attribution (CC BY) license (http://creativecommons.org/licenses/by/4.0/). 